\title{
PERANAN SURAT KABAR SOERAPATI DALAM PERLAWANAN INTELEKTUAL PRIBUMI DI JAWA BARAT TAHUN 1923- 1925
}

\author{
ROLE OF SOERAPATI NEWSPAPER IN INTELLECTUAL RESISTANCE \\ OF INDIGENOUS IN WEST JAVA 1923-1925
}

\author{
Dharyanto Tito Wardani \\ Program Studi Ilmu Sejarah, Fakultas Ilmu Budaya, Universitas Padjadjaran \\ Jl. Raya Bandung-Sumedang Km. 21 Jatinangor 45363 \\ e-mail: titowardani51@gmail.com
}

\begin{abstract}
Abstrak
Perlawanan intelektual pribumi yang dilakukan oleh organisasi berideologi komunis menggunakan beberapa media, diantaranya surat kabar Soerapati. Metode yang digunakan adalah metode sejarah yang terdiri atas empat tahapan kerja: heuristik, kritik, interpretasi dan historiografi. Konsep dan teori yang digunakan adalah konsep ruang publik Habermas dan teori konflik Dahrendorf. Hasil penelitian ini menyimpulkan bahwa surat kabar Soerapati pertama terbit setelah kongres PKI dan SR di Sukabumi pada tahun 1923. Hal ini diawali dengan perpecahan SI saat kongres di Madiun yang menghasilkan disiplin partai. PKI dan SR menggunakan media surat kabar Soerapati untuk melakukan perlawanan terhadap pemerintah kolonial dan pemerintah lokal, selain itu surat kabar Soerapati menjadi media perdebatan ideologi di internal organisasi pergerakan. Simpulan dari penelitian ini adalah perlawanan yang dilakukan oleh PKI dan SR berakhir dengan penangkapan dan pembuangan yang diberitakan di surat kabar Soerapati. Hal ini menjadi salah satu faktor surat kabar Soerapati harus disita dan dilarang terbit pada tahun 1925.
\end{abstract}

Kata kunci: Surat kabar Soerapati, Partai Komunis Indonesia (PKI), Sarekat Rakyat (SR).

\section{Abstract}

The Indigenous intellectual resistance carried out by communist ideology organizations using multiple media, including Soerapati newspapers. By used the historical method consists of four stages of work: heuristics, criticism, interpretation and historiography. Concepts and theories used is the public sphere concept of Habermas and conflict theory of Dahrendorf. The results concluded that newspapers first published after the congress Soerapati PKI and SR in Sukabumi in 1923. It was preceded by a split time SI congress in Madiun who produce a discipline party. PKI and SR Soerapati using the press to fight against the colonial and local governments, in addition to the Soerapati newspaper became the ideological debates media movement organizations internally. The conclusions is carried out by the resistance of the PKI and SR ended with the capture and disposal by newspapers Soerapati. This is one factor newspaper Soerapati be confiscated and banned in 1925.

Keywords: Soerapati newspaper, Indonesian Communist Parties (PKI), Sarekat Rakyat (SR) 


\section{A. PEndahuluan}

Pada abad ke-20 kebijakan pemerintahan kolonial di Indonesia mengalami perubahan dari kebijakan Liberal menuju kebijakan Etis. Hal ini didasari oleh pemikiran mengurangi penderitaan rakyat di Indonesia yang tertindas akibat praktik kerja paksa. Kebijakan pemerintah kolonial pada awalnya bersifat Konservatif (1830-1870) selanjutnya bersifat Liberal (1870-1900) dan Etis (1901). Kebijakan pemerintah kolonial tahun 1900 akhirnya memiliki tujuan baru, eksploitasi terhadap tanah dan penduduk pribumi mulai ditinggalkan. Salah satunya adalah karena semangat pemikiran mengenai kemanusiaan (humanism) mulai berkembang di Eropa.

Kebijakan pemerintah kolonial awalnya dinilai menghisap kekayaan tanah dan penduduk pribumi. Hal ini terlihat ketika politik kolonial membentuk batig slot (sistem keuntungan bersih). Sejak cultuurstelsel dijalankan, Hindia Belanda menyetorkan kelebihan uang ke Negri Belanda sejumlah antara 10.000 .000 sampai 40.000.000 gulden setiap tahun. Batig slot terakhir diterima pada 1877, negeri Belanda memperoleh keuntungan sebesar 825.000.000 gulden (Kartodirdjo, 2014:31-32).

Kebijakan ini pada dasarnya hanya untuk menopang kemakmuran Negri Belanda. Sehingga upaya untuk membayar jasa penduduk Hindia Belanda dilakukan melalui kebijakan Politik Etis. Utang kehormatan dibayarkan kembali dengan jalan memberi prioritas utama kepada kepentingan penduduk pribumi di dalam kebijakan kolonial (Ricklefs, 2008: 328). Politik Etis ini menitikberatkan perbaikan pada tiga hal yaitu, irigasi (sistem perairan), edukasi (pendidikan), dan emigrasi (penyebaran penduduk). Tiga prinsip politik etis ini akhirnya bisa dilaksanakan, meskipun pada dasarnya banyak berpusat di bidang pendidikan.

Pendidikan sangat berpengaruh bagi perubahan pemikiran dan mental pribumi di kemudian hari. Namun pendidikan untuk kaum pribumi pada politik etis awalnya hanya diperuntukkan kalangan elite tradisional (priyayi atau ménak). Kaum ménak sebagai elite politik yang duduk dalam birokrasi tradisional menggunakan kedudukan politik sebagai salah satu cara untuk mempertahankan status mereka (Hardjasaputra, 2002:2).

Sekolah di Bandung yang dibuat untuk golongan ménak disebut Hoofdenschool. Pemerintah kolonial mendirikan sekolah-sekolah, dari tingkat dasar sampai sekolah tinggi. Pendidikan tradisional untuk para ménak atau para priyayi akhirnya tidak memadai lagi untuk membentuk calon bupati, sehingga pemerintah kolonial merasa perlu mendirikan sekolah-sekolah khusus, yang disediakan hanya bagi putra-putra bangsawan agar mereka mendapatkan sebagian dari pengetahuan barat.

Pendidikan dan pengetahuan Barat mulai diterapkan kepada golongan penduduk pribumi. Bahasa Belanda menjadi bahasa pengantar di setiap sekolah-sekolahnya. Kebijakan tersebut mengakibatkan kedudukan pendidikan lapisan atas penduduk pribumi dan orang Belanda sama. Kesempatan ini diperluas oleh pemerintah kolonial dengan cara kesempatan untuk masuk sekolah pribumi seperti HIS diperluas dan kesempatan untuk belajar bahasa Belanda diperbanyak. Penduduk pribumi yang bukan berketurunan ménak atau biasa disebut golongan kuring mendapat kesempatan ketika didirikannya Vervolgschool yang merupakan lanjutan dari sekolah desa. Anak-anak dari sekolah desa dan sekolah kelas dua untuk mendapatkan pendidikan barat.

Pendidikan adalah latar belakang utama kemunculan satu kalangan baru dari lapisan social masyarakat pada waktu itu. Kalangan itu disebut dengan intelektual pribumi (pribumi terpelajar). Prinsip politik Etis yang bertujuan meningkatkan kondisi kehidupan penduduk pribumi dengan cara pemerintah mendirikan sekolah-sekolah, dari tingkat dasar sampai 
sekolah tinggi. Sehingga dalam dasawarsa pertama abad ke-20 terbentuk berbagai pergerakan yang banyak menggugat sistem kolonial (Lombard, 2008: 77-78).

Pergerakan di Indonesia pada tahun 1920 sampai 1930 banyak berasal dari organisasi-organisasi yang didirikan oleh kaum terpelajar di Indonesia. Organisasi-organisasi yang dibentuk oleh kaum terpelajar Indonesia terklasifikasi berdasarkan pemahamanan yang dianut oleh para anggota organisasi tersebut. Pergerakan Indonesia tahun 1920-1930 banyak menggunakan dasar ideologi. Salah satunya adalah Sarekat Islam (SI) dengan menggunakan ideologi Islam. Namun salah satu ideologi yang berkembang di Eropa pada tahun 1917-1925 adalah ideologi komunisme atau marxisme.

Perkembangan selanjutnya perbedaan cara pandang gerak perlawanan SI, SI harus dihadapkan pada permasalahan di tubuh internal organisasinya. SI kemudian terpecah. Hal ini disebabkan SI yang awalnya dipandang tidak revolusioner, perlu memikirkan dan mencari arah aksi baru. Aksi yang pernah dilakukan oleh beberapa orang, menamakan organisasinya afdelling $B$ pada tahun 1919 melakukan aksi pemberontakan di Cimareme Garut. Perkara afdelling $B$, kemudian SI mendapat cap revolusioner ${ }^{1}$ (Pringgodigdo, 1994:4).

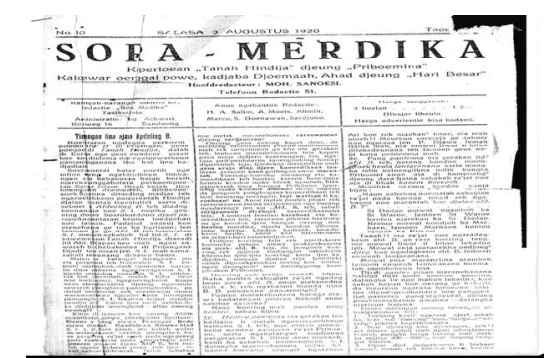

Gambar 1. Perkara Afdelling B tahun 1919 Sumber: Surat kabar Sora-Merdika 3 Agustus 1920

\footnotetext{
${ }^{1}$ Pada dasarnya SI menolak perkara afdelling $B$ adalah gerakan yang dilakukan oleh SI. Dapat dilihat di surat kabar Sora-Merdika No. 10 terbit pada tanggal 3 Augustus 1920.
}

Pergerakan Indonesia oleh SI radikal yang banyak menggunakan konsep komunisme dalam perlawanannya cenderung lebih aktif bahkan radikal. Hal ini dapat dilihat dari setiap kongres Central Sarekat Islam (CSI) pada tahun 1916 sampai 1924. Kalangan SI Radikal selalu mengkritik dan tidak sependapat dengan persoalan kebijakan yang dilakukan oleh pemerintah. Seperti contoh kebijakan Indie Weebaar pada tahun 1917, pajak dan kebijakan vlootwet (pengadaan kapal perang).

Surat kabar pada kurun waktu abad ke-20 sangat penting bagi alat perjuangan seluruh organisasi pergerakan di Indonesia. Periodisasi pergerakan nasional dengan menggunakan media surat kabar adalah salah satu alat propaganda yang paling efektif untuk memperluas atau memperbesar pengaruh ideologi masingmasing organisasi. Pers, karena sifatnya yang tertulis sehingga dapat dibaca berulang-ulang, merupakan media yang efektif untuk mempengaruhi dan membangun opini publik. Sejak awal pemerintah kolonial Belanda sudah menyediakan perangkat hukum untuk mengendalikan pers (Lapian et al.2012: 303).

$\begin{array}{ccc}\text { Surat kabar } & \text { pergerakan yang } \\ \text { menjadi perhatian } & \text { utama dalam }\end{array}$ perkembangan pemikiran intelektual penduduk pribumi adalah surat kabar yang berasal dari daerah Jawa Barat yaitu surat kabar Soerapati. Surat kabar ini terbit pertama kali pada tahun 1923 di Sukabumi. Surat kabar Soerapati pertama kali terbit berbarengan dengan Kongres SI Merah dan PKI di Bandung dan Sukabumi pada tahun $1923^{2}$.

Kongres yang dilakukan oleh SI Merah dan PKI pada tahun 1923 adalah bentuk kritik serta kekecewaan SI radikal. Hal ini merupakan puncak perpecahan

\footnotetext{
${ }^{2}$ Putusan dan hasil kongres SI Merah dan PKI yang diselenggarakan di Bandung dan di Sukabumi pada bulan Maret tahun 1923 dapat dilihat dari surat kabar Matahari yang terbit pada 17 April 1923.
} 
ditubuh SI setelah kongres SI di Madiun. Surat kabar Soerapati ini menggunakan bahasa Sunda sebagai bahasa pengantar dari setiap penerbitan surat kabarnya.

Pembatasan kurun waktu penelitian surat kabar Seorapati ini dimulai tahun 1923 sampai 1925. Hal ini didasarkan pada pertimbangan aspek temporal kajian historis yang dilaksanakan. Pada tahun 1923 surat kabar Soerapati mulai diterbitkan. Pada tahun 1924 dan 1925 surat kabar Soerapati ini sangat banyak berpengaruh karena berita-berita yang termuat di surat kabar ini banyak menuliskan tentang perkumpulan organisasi dan gerakan-gerakan komunisme di Hindia Belanda, khususnya di Jawa Barat. Surat kabar Soerapati yang terbit di dua tempat ini, Sukabumi dan Bandung ini akhirnya terhenti pada tahun 1925. Media ini menarik untuk dikaji karena media surat kabar Soerapati berideologi komunis ini banyak menuliskan permasalahan di Jawa Barat yang sangat sedikit diangkat ke permukaan.

Permasalahan seperti perdebatan antara kaum theosophie dan komunisme, perdebatan antara SI Putih (Agama) dan SI Merah (Sarekat Rakyat) di Bandung sampai peristiwa penembakan anggota PKI di Garut. Ketertarikan selanjutnya adalah bahasa yang digunakan oleh surat kabar Soerapati ini menggunakan bahasa Sunda sebagai bahasa propaganda dalam setiap penerbitannya.

Dalam artikel ini yang menjadi masalah utama adalah "Bagaimana peranan surat kabar Soerapati dalam perlawanan intelektual pribumi yang berideologi komunis di Jawa Barat pada tahun 1923-1925?". Rumusan masalah akan dibatasi dalam beberapa pertanyaan. Bagaimana kondisi organisasi pergerakan yang mengawali terbitnya surat kabar Soerapati? Bagaimana peranan surat-surat kabar selain Soerapati dalam debat secara ideologis di dalam media? Bagaimana perdebatan di tubuh organisasi SI (SI Merah dan SI Putih) dan peranan surat kabar Soerapati memandang perdebatan tersebut? Bagaimana peranan surat kabar Soerapati dalam perjuangan gerakan komunisme di Jawa Barat?

Berdasarkan rumusan masalah di atas, tujuan penulisan ini adalah untuk merekontruksi sejarah perlawanan dan perebutan ruang publik melalui surat kabar yang berideologi komunis di Hindia Belanda khususnya Jawa Barat. Secara terperinci tujuan penelitian ini mencakup empat hal, pertama menguraikan kondisi organisasi pergerakan yang menjadi radikal khususnya SI dan mengawali terbitnya surat kabar Soerapati di Sukabumi. Kedua menjelaskan peranan surat selain Soerapati dalam debat secara ideologis. Ketiga menganalisis setiap isi dari surat kabar Soerapati yang banyak memuat berita mengenai organisasi pergerakan, seperti Sarekat Islam (SI), Sarekat Rakjat yang muncul sebagai kekuatan yang dapat mengancam pemerintahan Hindia Belanda. Namun perdebatan ditubuh organisasi SI (SI Merah dan SI Putih) sendiripun selalu terjadi. Hal menjadi perdebatan di tubuh SI selalu terekam melalui media surat kabar termasuk surat kabar Soerapati. Keempat menjelaskan peranan surat kabar Soerapati dalam perjuangan gerakan komunisme di Jawa Barat.

\section{B. METOdE PENELITIAN}

Metode yang digunakan dalam penelitian ini adalah metode sejarah. Metode sejarah ialah suatu usaha untuk mempelajari dan mengenali fakta-fakta serta menyusun simpulan mengenai peristiwa masa lalu. Tujuannya untuk membuat rekonstruksi masa lampau secara sistematis dan objektif (Herlina, 2011:1; Gottschalk, 2008, Garraghan, 1957: 34).

Tahapan metode sejarah pada dasarnya terbagi dalam empat tahapan kerja. Tahap pertama adalah heuristik. Heuristik merupakan tahapan awal setelah menentukan topik atau permasalahan penelitian. Heuristik yaitu proses pencarian, menemukan dan menghimpun 
sumber sejarah yang terkait dengan pokok permasalahan. Tahap pencarian sumber dilakukan terhadap sumber tertulis berupa arsip, sumber resmi tercetak, dokumen, buku dan lain lain.

Pencarian sumber primer berbentuk sumber resmi tercetak surat kabar dilaksanakan di Perpustakaan Nasional Republik Indonesia (PNRI). Pencarian sumber sekunder berbentuk buku dilakukan di beberapa perpustakaan, antara lain di Bandung: Badan Perpustakaan dan Arsip Daerah Provinsi Jawa Barat (BAPUSIPDA), Perpustakaan Fakultas Ilmu Budaya UNPAD, Perpustakaan UNPAD, Perpustakaan Batu Api di Jatinangor.

Beberapa tulisan yang berkaitan dengan sejarah surat kabar secara umum telah dituliskan dalam bentuk disertasi, tesis, artikel dan buku. Secara spesifik penelitian mengenai sejarah perkembangan surat kabar Soerapati belum pernah dikaji. Sumber litelatur lain yang mendukung studi kepustakaan untuk menegaskan permasalahan yang berkaitan dengan persoalan peranan surat kabar Soerapati sebagai penyokong gerakan komunisme ini di antaranya adalah buku Indonesia dalam Arus Sejarah (IDAS) jilid V "Masa Pergerakan Kebangsaan" dan buku Sejarah Provinsi Jawa Barat.

Buku yang berjudul Indonesia dalam Arus Sejarah ini sangat penting karena memuat informasi beberapa surat kabar yang berafiliasi dengan PKI. Informasi dari buku ini mengenai surat kabar yang berafiliasi dengan PKI dituliskan dalam bentuk table. Dapat disimpulkan bahwa surat kabar Soerapati ini betul-betul berafiliasi dengan PKI. Buku ini menuliskan surat kabar yang berafiliasi dengan PKI dan terbit di Bandung adalah Matahari, Mataram, Soerapati, Titar (IDAS. 2012: 301).

Sumber literatur selanjutnya adalah buku "Sejarah Provinis Jawa Barat" yang ditulis oleh Tim Peneliti Sejarawan Jawa Barat. Pembahasan spesifik mengenai surat kabar dituliskan di buku "Sejarah Provinsi Jawa Barat" jilid kedua. Kehidupan sosial budaya di tengah pergerakan nasional berdampak pada perkembangan pers (surat kabar) di Jawa Barat. Buku ini sangat penting karena memuat informasi mengenai perkembangan surat kabar di Jawa Barat khususnya surat kabar yang berbahasa Sunda. Perkembangan surat kabar di Jawa Barat kemudian terlihat dari karakter surat kabar tersebut. Selanjutnya, Herlina menuliskan mengenai surat kabar penyokong gerakan Komunis yaitu surat kabar Soerapati. "Pada tahun 1923 di Sukabumi terbit surat kabar berbahasa Sunda yang menyokong gerakan Komunis, yaitu Soerapati. Surat kabar kiri itu dipimpin oleh seseorang yang bernama samaran "Si Oentoeng". Dengan suara vokal yang banyak menyerang kebijakan pemerintah kolonial dan juga pemerintah pribumi, surat kabar yang terbit tengah bulanan dijual murah yaitu 75 sen per tiga bulan dibayar di muka dan harga eceran seharga 15 sen. Sebagai surat kabar kiri, pada tanggal 1 Mei 1926 terbit dengan warna tinta merah, dalam rangka memperingati Hari Buruh Sedunia ${ }^{3}$. Surat kabar itu sangat radikal. Kadang-kadang memuat artikel yang dengan berani dan kasar memaki-maki seorang bupati pribumi yang dianggap berlaku sewenangwenang. Setelah pemberontakan komunis tahun 1926, surat kabar itu tidak pernah muncul lagi (Herlina,2013a: 131-132)".

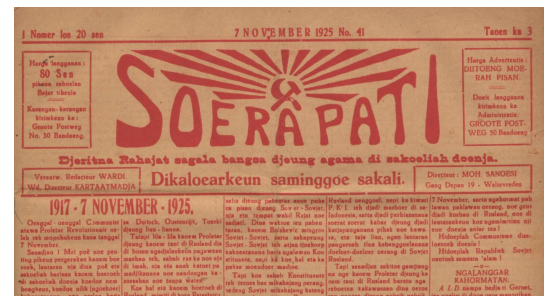

Gambar 2. Surat kabar Soerapati diterbitkan dengan tinta merah

Sumber: Surat kabar Soerapati 7 November 1925 No. 41.

\footnotetext{
${ }^{3}$ Surat kabar Soerapati yang ditulis dengan tinta merah diterbitkan pada tanggal 7 November 1925.
} 
Tahap kedua dalam metode sejarah adalah kritik. Kritik sumber sejarah terdiri atas kritik ekstern dan kritik intern. Kritik ekstern bertujuan untuk menentukan otentisitas sumber dengan cara memberikan penilaian terhadap kondisi fisik sumber tersebut, seperti jenis kertas yang digunakan, tinta, tulisan, huruf, watermerk, stempel dan sebagainya. Kritik intern dilakukan dengan melakukan penilaian instrinsik terhadap sumber tersebut.

Tahap selanjutnya adalah interpretasi, yaitu proses menafsirkan berbagai fakta menjadi sebuah rangkaian yang logis. Interpretasi dilakukan secara analitis dengan menguraikan fakta dan dilakukan secara sintesis yaitu menghimpun fakta. Fakta yang diperoleh diinterpretasikan baik secara teknis, logis, faktual dan psikologis. Dengan demikian, interpretasi yang dihasilkan dapat dipahami secara menyeluruh dan mendalam.

Tahap berikutnya adalah historiografi. Fakta yang telah diinterpretasikan dituliskan dalam penulisan yang sistematis dan kronologis. Historiografi yang akan dihasilkan dibagi menjadi beberapa bagian pembahasan.

Teori yang digunakan dalam penulisan ini adalah teori konflik dan konsep ruang publik Habermas. Teori konflik pada dasarnya berkembang sebagai reaksi terhadap teori fungsionalisme struktural dan akibat berbagai kritik. Teori konflik ini sebenarnya berasal dari berbagai sumber seperti teori Marxian (konflik kelas sosial) dan pemikiran konflik sosial dari Simmel. Namun pada dasarnya teori konflik Dahrendorf mengkritik teori konflik kelas sosial Marx. "Dahrendorf menyatakan bahwa kapitalisme telah mengalami perubahan besar sejak Marx mulai mengembangkan teori tentang konflik kelas. Sistem baru kapitalisme, yang ia identifikasi sebagai pasca kapitalisme (poskapitalisme), ditandai dengan struktur kelas yang beragam dan sistem relasi kekuasaan yang cair. Konflik kelas saat ini sudah terbiasa dengan serikat pekerja, perundingan bersama, sistem pengadilan, dan bahkan debat legislatif (Tittenburn: 2013: 119)".

Pada intinya teori konflik Dahrendorf sangat relevan dengan pembahasan peranan surat kabar Soerapati dalam perlawanan intelektual pribumi ini. Pertama, konflik kelas yang dijelaskan oleh Dahrendorf tidak lagi konflik kelas dalam status sosial dan ekonomi, melainkan melalui serikat pekerja (organisasi), dan debat pertemuan atau kongres. Surat kabar Soerapati memuat beberapa tulisan yang menggambarkan debat para anggota SI dalam setiap pertemuan (vergadering) atau kongres SI. Menjelaskan pula kegiatan Sarekat Pekerja dalam setiap aksi mogok.

Kedua teori konflik Dahrendorf menjelaskan tentang otoritas. Otoritas secara tersirat menyatakan superordinasi dan subordinasi. Mereka yang menduduki posisi otoritas diharapkan bisa mengendalikan bawahan. Artinya, kelompok yang berkuasa berada dalam posisi superordinat (pemerintah kolonial dan pemerintah lokal) dan yang dikuasai berada didalam posisi subordinat (rakyat dan intelektual pribumi yang tidak mempunyai posisi di dalam pemerintahan). Konflik kelas terlihat dalam struktur perebutan otoritas. Kelompok subordinat yang bertentangan dengan kelompok superordinat akan melahirkan kepentingan bersama.

Intelektual komunis penduduk Jawa Barat pada dasarnya mempunyai kepentingan-kepentingan bersama pada masa pergerakan nasional. Hal ini membuat satu kelompok yang bertentangan dengan kelompok pemilik kekuasaan yaitu pemerintahan kolonial. Intelektual komunis ini akhirnya mengumpulkan kepentingan-kepentingan bersama dalam suatu wadah organisasi untuk melakukan satu bentuk perlawanan baru. Perlawanan secara politik, perlawanan dengan menggunakan media 
organisasi dan surat kabar sebagai corong informasi.

Ruang publik pada dasarnya diartikan menjadi ruang atau tempat berkerumunnya manusia untuk melakukan semua komunikasi yang terjadi. Ruang publik secara umum diartikan sebagai tempat yang menjadi pusat dari proses interaksi manusia, maka dari itu ruang publik terdapat di mana saja. Salah satu tokoh yang memperhatikan perkembangan ruang publik ialah Jurgen Habermas. Habermas membagi konsep ruang publik menjadi tiga jenis. Hal ini dijelaskan sebagaimana berikut:

"Ruang Publik yang memiliki makna beragam seperti '(sang) publik', 'ruang publik', atau 'publisitas' mengacu ke dalam pengertian ruang publik. Dibedakan menjadi tiga jenis:

1. Ruang Publik Politik; artinya 'ruang publik politis' (atau kadang-kadang diterjemahkan dalam frase lebih panjang menjadi 'ruang publik di wilayah politik/politis').

2. Ruang Publik Literatur; diartikan sebagai 'ruang publik sastra/literer' (atau 'ruang publik di dunia sastra/tulismenulis), dan

3. Ruang Publik Representasi; artinya "ruang publik representasi/perwakilan" ruang publik yang pertunjukan kekuatan spiritual inheren atau kehormatan di depan khalayak yang menonton (Habermas, 2010:xi).

Ruang publik mempunyai definisi yang luas. Perkembangan mengenai ruang publik yang bergeser ke arah ruang publik politik menurut pemikiran Habermas ini menjadi awal dari gerakan perlawanan masyarakat dalam diskursus teori kritis. Teori kritis yang dikembangkan oleh para pemikir atau filsuf yang menolak gagasan awal Marx. Menurut Bernstein dan Kellner teori kritis adalah produk sekelompok pemikir marxisme baru, berasal dari Jerman yang tidak puas dengan keadaan teori Marxian (Goodman, 2007: 176). Teori kritis sebagian besar terdiri atas kritik terhadap berbagai aspek kehidupan sosial dan intelektual. Habermas dan teori ruang publiknya adalah salah satu pemikir dari mazhab frankfurt ${ }^{4}$.

Kelas intelektual sebagai subjek perubahan kelas sosial, dalam sejarah Indonesia pada masa pergerakan berada di lingkungan terpelajar. Pergeseran arti dari perkembangan ruang publik yang dikemukakan oleh Habermas ini menjadi dasar pemikiran sejarah perlawanan surat kabar Soerapati yang berada di Jawa Barat tahun 1924. Pada dasarnya meskipun Jurgen Habermas lahir setelah tahun 1924 perebutan ruang publik yang terjadi di Jawa Barat pada awal tahun 1924 sangat relevan untuk mendasari gerakan perlawanan surat Kabar Soerapati yang berideologi komunis.

Ruang publik politik yang dilandasi oleh pemikiran Habermas ini menjadi ruang tempat kaum terpelajar penduduk pribumi menyatakan opini-opini, kepentingan-kepentingan, dan kebutuhankebutuhan mereka secara diskursif di dalam media surat kabar masuk ke dalam ruang publik politik. Ruang publik menjadi tempat masyarakat dapat menyatakan opini-opini, kepentingan-kepentingan dan kebutuhan-kebutuhan mereka secara diskursif (Hardiman, 2009: 133). Jadi, perlawanan yang dilakukan oleh surat kabar Soerapati dalam kurun waktu 19231925 ini adalah perlawanan terhadap pemerintah kolonial dan pemerintah lokal dengan gaya baru, perlawanan yang tidak menggunakan senjata melainkan dengan menggunakan intelektual dan jurnalistik.

\section{HASIL DAN BAHASAN \\ 1. Kondisi Pergerakan SI pada Tahun 1915-1920}

Pergerakan nasional muncul melalui organisasi modern. Kebutuhan akan interaksi sosial di kalangan intelektual

\footnotetext{
${ }^{4}$ Mazhab Frankfurt ialah sebuah nama yang diberikan kepada kelompok filsuf yang memiliki afiliasi dengan Institut Penelitian Sosial di Frankfurt Jerman. Mazhab Frankfurt adalah sebuah nama organisasi yang berkaitan dengan teori kritis (Goodman, 2008: 176).
} 
pribumi diwadahi dalam satu ikatan yang sama secara ideologis maupun secara primordial. Karakteristik organisasi pergerakan nasional dapat diidentifikasi dari pemahaman yang dianut oleh para anggota organisasi tersebut. Intelektual pergerakan yang diilhami oleh tradisi Jawa membentuk Boedi Oetomo pada tahun 1908 dan organisasi yang diwakili oleh pedagang Islam membentuk Sarekat Dagang Islam (SDI).

Kebangkitan SDI dimulai pada tahun 1912. Hal ini diawali ketika salah satu ketua SDI dari Jawa Timur mempunyai gagasan perubahan untuk SDI. Ia adalah H.O.S Tjokroaminoto. Tjokro mengubah nama organisasi Sarekat Dagang Islam (SDI) menjadi Sarekat Islam (SI). Pemikiran Tjokro perubahan nama Organisasi SDI menjadi SI memiliki cakupan lebih luas lagi, jika sebelumnya SDI merupakan sebuah organisasi dagang Islam, SI kini tidak hanya meliputi bidang perdagangan dan usaha.

SI dapat masuk ke seluruh bidang yang menjadi aspirasi penduduk pribumi. SI akhirnya ikut dalam organisasi pergerakan politik di Hindia Belanda. Sejak tahun 1912 SI berkembang sangat pesat, dan pertama kalinya basis rakyat berada di dalam organisasi ini. Tahun 1919 buat SI adalah tahun berkembang pesatnya propaganda kapital asing, hal yang dihantam oleh SI. Jumlah anggota SI pada tahun 1919 sampai dua juta orang $^{5}$ (Pringgodigdo, 1994: 9).

SI yang sebelumnya merupakan asosiasi para pedagang Islam, saat ini menjadi organisasi yang dapat merengkuh

\footnotetext{
5 Ada dua pendapat lagi mengenai keanggotaan SI yang mencapai 2 Juta orang. Pertama menurut Pronggodigdo tahun 1919 adalah tahun berkembang pesat organisasi SI karena propaganda yang dilakukan untuk menghantam kapital asing. Kedua menurut Ricklefs. Pada tahun 1919 SI menyatakan mempunyai anggota 2 juta orang, tetapi jumlah yang sesungguhnya mungkin tidak pernah lebih dari setengah juta orang (Ricklefs, 2008: 360).
}

seluruh bidang yang menjadi aspirasi kaum pribumi. Berbeda dengan gerakan-gerakan lainnya, SI merupakan organisasi total artinya tidak terbatas pada satu orientasi tujuan tetapi mencakup berbagai bidang aktivitas, yaitu ekonomi, sosial, politik, dan kultural. Tambahan pula di dalam gerakan itu lebih merupakan suatu revivalisme (kebangkitan), yaitu hidupnya kembali kepercayaan dengan jiwa atau semangat yang berkobar-kobar (Kartodirjo, 2014:124).

SI sebagai organisasi politik mempunyai corong media surat kabar propaganda politiknya yaitu surat kabar Oetoesan Hindia. Namun pada dasarnya izin pendirian SI setiap cabang berdiri sendiri (otonom). Fungsi otonom di setiap cabang SI akhirnya memberikan warna gerakan SI di setiap daerah bervarian. Dengan minimnya informasi dan tidak adanya koordinasi setiap cabang SI daerah dengan pengurus pusat, membuat corak organisasi ini sangat beragam ketika menafsirkan perjuangan SI. Pergerakan SI ditafsirkan oleh setiap cabang SI daerah sesuai dengan kepentingannya masingmasing. Termasuk salah satu cabang SI di Semarang yang dipimpin oleh Semaoen, menafsirkan SI sebagai gerakan perjuangan berbasis rakyat dan buruh.

Di Tasikmalaya Jawa Barat SI merupakan gerakan pencerahan yang dinilai dapat membuat perbaikan masyarakat di Tasikmalaya. SI yang memiliki visi emansipasi untuk rakyat di Hindia Belanda diperlihatkan dengan tujuan berikut. Pertama, SI memajukan semangat dagang di kalangan bumi putra. Kedua, SI memberikan bantuan kepada anggota perkumpulan, yang karena bukan kesalahannya dan tiada dengan kesengajaan berada dalam macam-macam kesulitan. Ketiga, memajukan pendidikan rohani dan kepentingan materil bumiputra demikian juga membantu meningkatkan kedudukan bumi putra; keempat menghilangkan salah pengertian tetang agama Islam dan memajukan kehidupan keagamaan di kalangan bumi putra sesuai 
dengan hukum tata cara dan agama tersebut; kelima, menempuh segala cara dan menggunakan semua jalan yang diperkenankan dan tidak bertentangan dengan ketenteraman umum dan adat istiadat yang baik (Salam, 2013: 73).

Di Surakarta SI adalah gerakan nasionalis, demokrasi, religius dan ekonomi. Di kalangan rakyat jelata SI bermusuhan dengan Tionghoa; perkelahian dengan maksud "menghajar" sering terjadi. Karena kuatir hal ini lambat laun akan menjadi gerakan melawan pemerintah, maka pada tanggal 12 Agustus 1912 SI diskors oleh Residen Surakarta, yaitu dilarang menerima anggota baru dan mengadakan rapat (Pringgodigdo,1994:5).

Di beberapa tempat timbul gerakan anti-Cina, terutama karena mereka dipandang sebagai pengahalang usaha ekonomi pribumi, antara lain si Sala (Surakarta), Bangil, Tuban, Rembang, Cirebon, Kudus (1918). Dalam hal ini antagonisme ekonomis diperkuat oleh perbedaan agama. Keresahan di sekitar Batavia terjadi dan kemudian timbul insiden, antara lain bentrokan antara pengikut SI dengan pengusaha perjudian dan pelacuran; bentrokan antara wariswaris, yang dalam sengketa itu salah satu pihak tertindas atas nama SI (Kartodirdjo, 2014: 124-125).

Hubungan antara cabang SI daerah dan pusat akhirnya dilakukan. Tjokroaminoto akhirnya membentuk satu badan khusus yang bekerja untuk memajukan dan membantu hubungan komunikasi SI daerah dengan SI pusat. Badan itu disebut Central Sarekat Islam (CSI) dan didirikan pada tahun 1915. Namun SI harus dihadapkan pada permasalahan serius di internalnya. Masuknya paham Komunis dan Sosial Demokrat pada tahun 1914 (1 tahun sebelum CSI dibentuk) mewarnai SI menjadi radikal. Hal ini diawali ketika ideologi komunisme dari organisasi ISDV mulai masuk ke dalam tubuh organisasi SI di Semarang yang dipimpin oleh Semaoen.
SI cabang Semarang pada perkembangan selanjutnya sama dengan gerakan ISDV.

Hal ini ditambah setelah dibuangnya Sneevliet, ISDV menjadi organisasi yang banyak anggotanya orang Indonesia. Tidak menutup kemungkinan gerakan yang selalu dilaksanakan oleh SI Semarang seperti mogok, demonstrasi dan propaganda di setiap surat kabarnya (Sinar Hindia/Sinar Djawa), membuat SI Semarang terlihat sangat berpihak kepada rakyat pribumi. SI yang dipimpin oleh Tjokro semakin lama semakin tidak menarik. Tulisan-tulisan Tjokroaminoto akhirnya tidak lagi dianggap cemerlang dan luar biasa seperti biasanya ${ }^{6}$. Perpecahan di tubuh SI tidak dapat dihindari lagi, perbedaan cara pandang dan perdebatan di setiap kongres SI dan CSI membuat awal perpecahan SI memuncak pada tahun 1923 dengan hasil kongres disiplin partai yang memecat setiap anggota SI yang beranggota ganda terlebih anggota SI yang juga menjadi anggota PKI.

\section{Dinamika Perkembangan 0 rganisasi Sarekat Islam}

Pada tanggal 27-29 Oktober 1924 surat kabar Kaoem Kita menulis artikel yang berjudul "Jang Melemahkan Pergerakan Boemipoetra”. Artikel ini menjelaskan mengenai peran Central Sarekat Islam (CSI) pada awal pembentukannya di tahun 1916 hingga tahun 1924. Dituliskan selalu ada penyerangan kepada anggota SI yang termasuk ke dalam CSI. Penyerangan tersebut dilakukan oleh SI "Semarangan",

Perdebatan di internal organisasi SI dimulai pada tahun 1917. CSI pada saat itu mengadakan kongres kedua di Jakarta dengan hasil SI ingin mempunyai pemerintahan sendiri (kemerdekaan) untuk Hindia Belanda. SI akhirnya mencalonkan kader terbaiknya untuk Volksraad yaitu

\footnotetext{
6 ANRI. Sarekat Islam Lokal. (1975:161) Jakarta.

${ }^{7}$ Surat kabar Kaoem Kita Nomor 9, 27 Oktober 1924
} 
Tjokroaminoto dan Abdoel Moeis. SI cabang Semarang yang menolak untuk SI masuk ke dalam volksraad mengawali perdebatan elite SI dalam pandangan pergerakan yang menjadi awal perpecahan di internal SI. Kekecewaan SI sayap radikal yang dipimpin oleh Semaoen ditambah dengan pernyataan sikap Abdoel Moeis yang sepakat dengan Indie Weerbaar.

Hasil kongres CSI yang sepakat dengan Volksraad dan gerakan Indie Weerbaar ditolak oleh beberapa SI lokal. Salah satu SI lokal yang mengutuk keras putusan kongres mengenai Indie Weerbaar ini berasal dari SI Semarang yang dipimpin oleh Semaoen. Semaoen sebagai ketua SI cabang Semarang menegaskan bahwa : "Kami tidak soeka, keloearken darah oentoek keperloean orang lain, apalagi keperloean "zondig-kapitalisten" (Kapitalisme besar yang tidak menguntungkan)" ${ }^{\circ}$. Hampir setengah dari anggota kongres CSI yang hadir mendukung pernyataan Semaoen, namun suara mayoritas menolak pernyataan Semoaen hingga akhirnya konflik di tubuh SI tidak dapat dihindarkan lagi.

Tjokrominoto yang mempunyai pandangan sosialisme pada kongres keempat CSI tahun 1920. CSI akhirnya dapat merealisasikan gerakan SI ke dalam gerakan praktis perlawanan terhadap pemerintahan kolonial dan pemilik modal swasta pabrik dan perkebunan. Kongres keempat CSI ini membahas persoalan sebuah organisasi sentral untuk kaum buruh yang berada di dalam naungan CSI. Tjokro ingin tidak ada perseteruan dan konflik di tubuh SI, Tjokro pun memperlihatkan bahwa haluan ideologi SI pada dasarnya condong ke arah Sosialisme yang menolak Kapitalisme. Akhirnya Tjokro mulai mengambil alih organisasi Persatoean Pergerakan Kaoem Boeroeh (PPKB) sebagai organisasi buruh yang bernaung di bawah CSI, juga memasukkan

\footnotetext{
${ }^{8}$ Surat Kabar. Sinar Hindia. 8 Mei 1918.
}

beberapa anggota SI yang berasal dari SI sayap radikal menjadi pengurus PPKB.

PPKB pertama kali dibentuk memberikan kewenangan seluas-luasnya kepada SI Cabang Semarang yaitu Semaoen. Namun karena kegagalan Semaoen dalam aksi pemogokan PPKB menjelang tahun 1920. PPKB akhirnya diambil alih oleh Agus Salim. Semaoen yang kecewa dengan pengambilalihan ini membuat SI kembali berdinamika di tubuh internalnya bagi elite pengurus CSI.

Kondisi pergerakan organisasi SI pada tahun 1921 terjadi kembali. Kongres CSI di Yogyakarta pada bulan Maret 1921 menghasilkan dukungan SI terhadap PanIslamisme. SI sayap radikal yang sudah terwarnai ideologi komunisme menolak cita-cita Pan-Islamisme ${ }^{9}$. H. Fachrudin salah satu pengurus SI dan wakil ketua Muhammadiyah pada saat kongres CSI di Yogyakarta mengedarkan brosur yang menyatakan bahwa Pan-Islamisme tidak akan bisa terwujud bila bekerja sama dengan komunis. Karena komunis dan agama adalah dua hal yang saling bertentangan. Agus Salim mengecam bahwa SI cabang Semarang mendukung PKI. Pada dasarnya SI cabang Semarang menolak pencampuran antara agama dan politik di dalam tubuh SI. Namun pada akhirnya Tjokro lebih sepakat dengan citacita Pan-Islamisme.

Setelah kongres CSI di Yogyakarta pada tahun 1921. SI terpecah secara ideologis, terminologi SI "Putih" dan SI "Merah" pun lahir karena hasil dari kongres Yogyakarta. SI "Putih" yang berlandaskan agama setuju dengan PanIslamisme, dan SI "Merah" yang berlandaskan komunisme menolak cita-cita Pan-Islamisme. Perpecahan ditubuh SI pada kongres keenam di Yogyakarta ini menjadi puncak dari pertentangan antara SI sayap radikal dan CSI. Desakan Agus

9 Hasil keputusan comitren (Perkumpulan Partai Komunis di dunia) menolak cita-cita Pan-Islamisme. ISDV yang diubah nama menjadi Partai Komunis Hindia oleh Semaoen masuk ke dalam comitren. 
Salim dan Abdoel Moeis mengenai disiplin partai diusulkan. Disiplin partai yang melarang keanggoaan rangkap di organisasi SI menjadi sebuah keputusan untuk kongres selanjutnya. Anggota SI akhirnya harus dihadapkan pada pilihan SI atau organisasi (partai) lain, hal ini juga bertujuan agar SI bersih dari unsur-unsur komunisme. Hal ini menjadi kekhawatiran bagi anggota SI yang merangkap dengan PKI. Tan Malaka di kongres tersebut mengusulkan pengecualian bagi PKI. Namun usul dari Tan Malaka ditolak karena suara mayoritas dari kongres tersebut menyetujui disiplin partai.

Kongres CSI selanjutnya dilaksanakan pada bulan Februari tahun 1923 di Madiun. Kongres ini membahas disiplin partai dan mengeluarkan anggotaanggota yang SI yang merangkap dengan organisasi lain. Anggota SI yang merangkap dengan PKI, Muhammadiyah dan Persis turut dikeluarkan. Pada kongres ini Tjokro memusatkan pendidikan bagi kader CSI dan mengubah nama CSI menjadi Partai Sarekat Islam (PSI). Selanjutnya Shiraishi menuliskan:

"Kongres CSI di Madiun dihadiri 117 delegasi yang mewakili 40 SISI lokal. Meskipun SI Semarang, begitu juga pimpinan SI Komunis di Madiun, Cepu, Nganjuk, dan Bandung mengirimkan delegasinya. PKI telah menduga hasilnya sehingga Semaoen tidak hadir. SI/PKI Semarang mengirim Soekindar sebagai wakil, sementara SI Nganjuk, Madiun dan Bandung mengirim Soenarjo, Soekirno dan Mohammad Sanoesi sebagai delegasi mereka. Tjokroaminoto mengumumkan bahwa 45 dari 52 SI-SI lokal yang berpartisipasi dalam kongres adalah untuk organisasi PSI. Delegasi SI Madiun dan nganjuk mengajukan usul untuk membuat perkecualian disiplin partai bagi PKI. Tetapi, karena dipotong oleh suara marah para hadirin, keduanya harus berhenti berbicara di tengah jalan. Salim

mengatakan bahwa PKI membahayakan kesatuan Islam dan Tjokroaminoto menyatakan, "SI mempercayakan segala sesuatunya kepada Allah, sedang PKI tidak bersikap kepada Allah". Tjokroaminoto juga mengumumkan bahwa ia akan mengunjungi tempat-tempat dimana SI lokal ada di bawah kontrol komunis serta akan dibentuk afdeling SI dan PSI tandingan" (Shiraishi, 2005: 327328).

Kongres di Madiun ini merupakan satu kemunduran bagi SI, dan menjadi babak baru bagi Sarekat Rakjat. Menanggapi kongres CSI di Madiun, para pemimpin PKI mengadakan kongres PKI dan SI Merah pada awal Maret 1923 di Bandung dan Sukabumi ${ }^{10}$. Semaoen mengambil langkah lain, ia menyatakan jika SI mengabaikan sayap kirinya, SI akan kehilangan sebagian massa progresif dan SI akan kembali menjadi sebuah sarekat kecil pedagang muslim (McVey, 2009: 171).

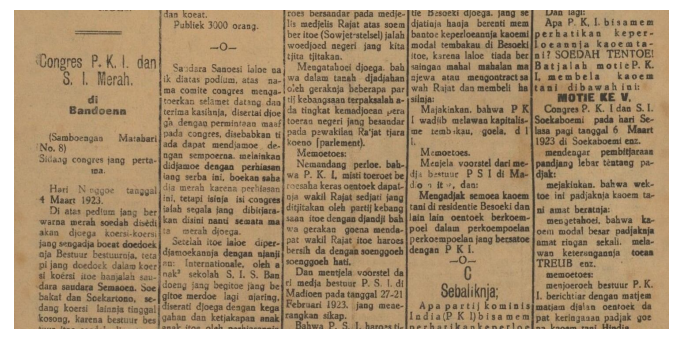

Gambar 3. Kongres PKI dan SI Merah di Bandung

Sumber : Surat kabar Matahari 17 April 1923 No. 10

Kongres PKI dan SI Merah pada tanggal 4 Maret 1923 dihadiri oleh perwakilan PKI dan SI merah. Perwakilan PKI ada 15 cabang: Bandung, Semarang, Wirosari, Yogyakarta, Salatiga, Madiun,

10 Kongres SI Merah dan PKI yang dilaksanakan di Bandung dan Sukabumi dituliskan didalam surat kabar Matahari yang terbit pada tanggal 17 April 1923. 
Sumedang, Sukabumi, Rancaekek, Solo, Cirebon, Surabaya, Randublatung, Bogor dan Cicalengka. Perwakilan dari SI merah lokal ada 13 cabang: Semarang, Wirosari, Bandung, Tasikmalaya, Yogyakarta, Purwokerto, Salatiga, Madiun, Sumedang, Sukabumi, Kaliwungu, Kendal dan Ungaran. Hasil dari kongres PKI dan SI merah di Bandung di antaranya adalah PKI dan SI Merah wajib melawan kapitalisme tembakau, gula dll.

PKI dan SI sedjati mendjadi satoe. Dari sebab itoe. Dalam Congres PKI dan SI-SI Merah (SI Sedjati) tanggal 6 Maret di Soekaboemi soedah di poetoes:

PKI dan SI-SI Merah bersatoe dalam satu badan. Peratoeran dengan pendek begini:

1. Di tiap-tiap tempat dimana ada SI Merah mesti didirikan tjabang PKI

2. SI Merah dan PKI di itoe tempat misti bekerdja bersama-sama

3. Dalam bekerdja bersama-sama itoepoen mereka haroes melawan kapitalisme

4. Semoea oeroesan besar haroes diteroeskan oleh tjabang PKI dan SI Merah di tempat itoe pada hoofdbestuur PKI Semarang, adrevoorzitter Semaoen Semarang.

5. Saban tahoen sekali atau dimana ada perloenja PKI bikin Congres dimana oetoesan-oetoesan SI Merah dan PKI menentoekan sikap-sikap goena membela keperloeannja rajat Hindia.

6. Lokal-lokal SI Merah tidak perloe bajar contributie pada PKI hanja mesti mengongkosi oetoesan-oetoesan ke Congres saja satoe tahoen sekali.

7. Modal PKI haroes didapat dari tjabangtjabang PKI (80\% Contributie jang masoek di tjabang PKI misti di stort pada Hoofdbestuur PKI).

8. SI-SI Merah dengan begitoe poenja modal tjoekoep boeat membela lid-lidnja, sebab tidak oesah bajar contributie pada Hoofdbestuur PKI dan djoega tidak perloe kirim ongkos boeat propagandist-propagandist PKI dan SI Merah, seperti Hadji Misbach, saudara Darsono, Abdoelrachman, dan lainlain lagi ongkos djalan propagandist- propagandist kita akan dibajar oleh modal PKI jang akan terdapat dari lidlid PKI.

9. Dimana masih ada SI Kapitalist dl Tjokroaminoto disitoe PKI akan bikin tjabang PKI dan Sarekat-Rajat (SR) jang akan kerdja bersama-ama di tempat itoe dengan PKI precies sebagai di lain-lain tempat PKI dan SI merah kerdja bersama-sama.

10. Keterangan lebih djaoeh saudarasaudara boleh minta pada Hoofdbestur PKI sekarang soedah njatalah, bahwa SI Merah, PKI serta kemoedian Sarekat Rajat mendjadi satoe (Surat Kabar Matahari, 17-April-1923).

Bersamaan dengan kongres SI Merah dan PKI di Bandung dan di Sukabumi pada tanggal 20 Oktober 1923 terbit surat kabar Soerapati di Sukabumi. Surat kabar Soerapati ini terbit sebagai surat kabar penyokong gerakan komunis di Jawa Barat dan menggunakan bahasa Sunda sebagai bahasa pengantar disetiap edisi penerbitannya, berbeda dengan surat kabar Matahari yang diterbitkan di Bandung dengan berbahasa melayu. Sebagai salah satu surat kabar yang terbit pada tahun 1923 dan menjadi penyokong gerakan organisasi yang berideologi Marxis terbit di Sukabumi karena sudah menjadi basis PKI dan SI Merah. Hal ini dapat kita lihat ketika kongres PKI dan SI Merah di Bandung dan Sukabumi delegasi cabang Sukabumi mengirimkan anggota PKI dan SI Merah.

Penulisan mengenai kritik kepada pemerintahan kolonial selalu dilakukan. Surat kabar Soerapati-pun selalu menuliskan kritik tentang konsep kapitalisme, dalam bahasa surat kabar Soerapati adalah “Kamodalan”. Kritik mengenai kapitalisme ditulis dengan teoretis, namun tidak menutup kemungkinan tulisan bentuk propaganda bahkan agitasi yang menghasut dan menyalahkan sistem kapitalisme, rata-rata ditulis dengan nada emosi. Beberapa artikel yang ditulis di dalam surat kabar itu sangat menarik. 


\section{Peranan Surat-surat Kabar Progresif Pada Tahun 1920-1923.}

Surat kabar cetak pertama kali ada di Hinda Belanda pada tahun 1744. Surat kabar itu adalah "Bataviasche Nouvelles en Politique Raisonnementes" sering dipendekkan menjadi "Bataviasche Nouvelles" (Soebagijo, 1977: 7). Perkembangan surat kabar pada tahun 1920 mempunyai khasanah pers Indonesia yang beragam. Hal ini disebabkan munculnya surat-surat kabar milik setiap organisasi termasuk PKI yang menuliskan kepentingan organisasinya. Terdapat lebih dari 20 penerbitan surat kabar yang berafiliasi dengan PKI dan terbit di berbagai kota, beberapa surat kabar yang progresif di Hindia Belanda di antaranya adalah Sinar Hindia (Semarang), Oetoesan Hindia (Soerabaja), Rakjat Bergerak (Solo), Matahari (Bandung), Halilintar (Pontianak), Panggoegah (Djokja), Soera

Rakjat (Semarang), Soerapati (Bahasa Sunda di Soekaboemi), Djago! Djago (Padang Pandjang), Pemandangan Islam (Padang-Pandjang).

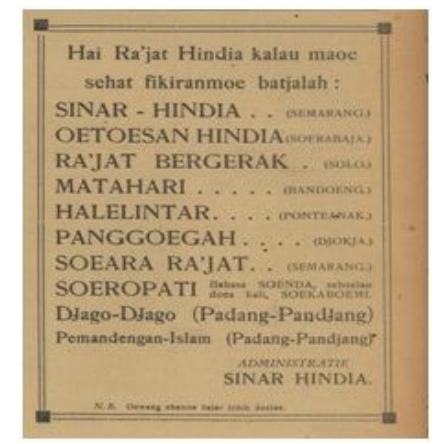

Gambar 4. Beberapa Surat Kabar yang berafiliasi dengan PKI

Sumber: Surat Kabar Sinar Hindia. 7 Februari 1924.

Menurut B. Schireke, penasihat pemerintah kolonial untuk urusan bumiputra, pada 1920 terdapat 107 surat kabar dan majalah yang dikelola oleh bumiputra yang dibedakan atas berbagai karakter, yaitu nasional, liberal, radikal, komunis, netral, dan perdagangan (Lapian, 2012: 300). Afiliasi beberapa surat kabar progresif yang mempunyai ideologi komunis terbit di beberapa kota dengan menggunakan bahasa Melayu dan bahasa Sunda, untuk surat kabar progesif di Jawa Barat ada dua yaitu surat kabar Matahari dan surat kabar Soerapati.

Surat kabar Matahari yang terbit di Bandung menggunakan bahasa Melayu sebagai bahasa pengantar dalam setiap penerbitannya. Surat kabar Soerapati menggunakan bahasa Sunda sebagai bahasa pengantar dalam setiap penerbitannya. Keterkaitan antara surat kabar Matahari dan surat kabar Soerapati dapat kita lihat dari terbitan tahun 1924 dan awal 1925. Kedua surat kabar tersebut menggunakan kalimat yang sama di halaman muka surat kabar tersebut.

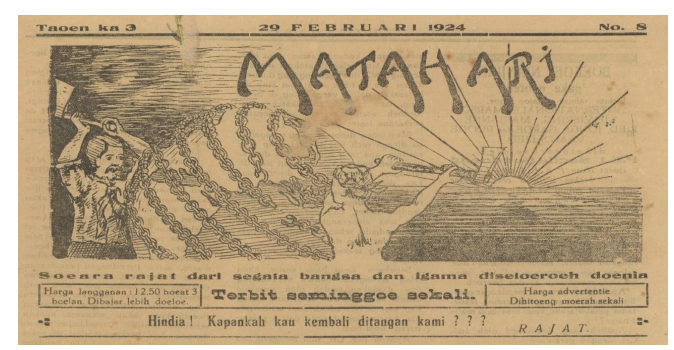

Gambar 5. Surat kabar Matahari ("soeara rajat dari segala bangsa dan igama diseloeroeh doenja")

Sumber: Surat kabar Matahari. 29 Februari 1924 No. 8

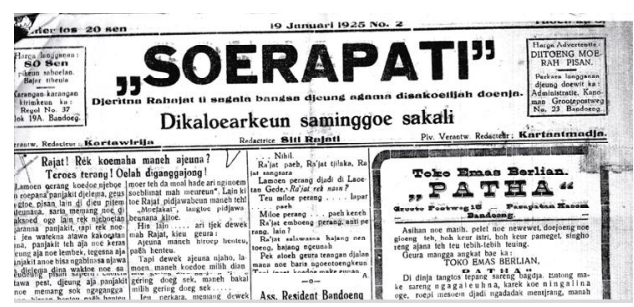

Gambar 6. Surat kabar Soerapati ("djeritna rahajat ti sagala bangsa djeung agama disakoelijah doenja")

Sumber : Surat kabar Soerapati. 9 Januari 1925 No. 2

Surat kabar Matahari dan surat kabar Soerapati mempunyai kalimat pembuka yang sama ketika awal tahun 1924-1925. Kalimat pembuka tersebut tertulis "Suara rakyat dari semua bangsa dan agama di seluruh dunia". Keterkaitan 
antara surat kabar Soerapati dan surat kabar Matahari diperlihatkan dengan kedua surat kabar ini menjadi official PKI untuk bahasa Melayu dan bahasa Sunda dari kongres SI Merah dan Sarekat Rakyat pada 20 dan 21 April 1924 di Bandung.

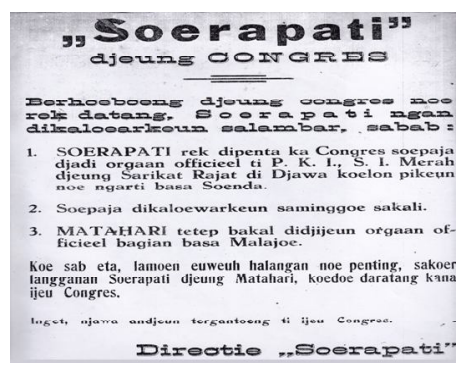

Gambar 7. Kongres SI Merah dan Sarekat Rakyat (SR)

Sumber: Surat kabar Soerapati. 20 April 1924.

\section{Peranan Surat Kabar Soerapati: Memandang Perdebatan SI dan SR}

Selanjutnya selain surat-surat kabar progresif yang brafiliasi dengan PKI. Di Jawa Barat pun terbit beberapa surat kabar berhaluan nasionalis dan agama. Salah satu surat kabar yang berhaluan Nasionalis adalah surat kabar Kaoem Kita. Surat kabar ini sangat penting untuk organisasi pergerakan. Meskipun tidak termasuk ke dalam surat kabar jaringan komunis. Surat kabar pernah memuat tentang pertentangan yang terjadi di antara pergerakan kaum pribumi. Kritik tentang perpecahan di tubuh SI oleh Kaoem Kita ditulis secara berkala pada terbitan 27 Oktober, 28 Oktober, dan 29 Oktober tahun 1924. Artikelnya diberi judul "Jang Melemahkan Pergerakan Boemipoetra” dituliskan sebagai berikut: "...Selainnja dari itoe akan tegoeh poela pendirian pergerakan, kalau aman soesoenannja, dan kalau aman keadaannja dalam sidang pemimpin. Tapi makin banjak ditimboelkan perselisihan makin longgarlah peroemahan pergerakan itoe, achirnya ia poen roeboeh. (Surat Kabar Kaoem Kita, 27 Oktober 1924 No.9)".

Perselisihan di dalam sidang para pemimpin, perselisihan yang berada di dalam organisasi itu sudah tentu tidak boleh didiamkan begitu saja. Penyerangan yang dilakukan oleh CSI kepada "Semarangan" (SI Merah di Semarang) diawali dari tahun 1916 sampai 1921. Akhirnya ketika SI pecah karena kongres Madiun dan SR di Sukabumi nyatalah lemah CSI. Artikel ini ditulis oleh orang yang berinisial A.M (kemungkinan yang menulis Abdoel Moeis).

Menanggapi persoalan perpecahan di tubuh SI surat kabar Soerapati selalu menuliskan jalannya perdebatan antara PKI dengan PSI di beberapa vergadering, salah satunya pertemuan yang dilaksanakan di gedung S.I.S. ruang pertemuan, Bandung pada tanggal 25 November 1923. Debat ini disebabkan SI Garut (SI Tjokro) menantang PKI Bandung.

Jalannya pertemuan ini dimulai Pukul 9 pagi. Vergadering dibuka oleh Winanta yang menerangkan maksud dan tujuan membuat pertemuan ini. Winanta memberikan kesempatan kepada peserta yang hadir dalam pertemuan ini untuk bersedia menjadi voorzitteren yang memimpin jalannya vergadering. Para hadirin dari pihak PKI dan PSI yang hadir sangat banyak, dituliskan bahwa dari pukul 7 pagi orang-orang sudah masuk mengisi ruang-ruang di S.I.S untuk melihat acara vergadering ini.

Goenawan terpilih menjadi voorzitteren untuk memimpin vergadering, dan disepakati oleh pihak PSI. Sebelum vergadering dibuka pihak PKI dan PSI diberikan kesempatan untuk menerangkan. Setelah sepakat vergadering dibuka. Pihak dari PSI Soeroso berbicara lebih dulu, dari kedua belah pihak diberikan waktu yang sama yaitu satu jam untuk menerangkan. Vergadering ribut karena Soeroso tidak menetapkan agenda yang dibawa dari PSI, melainkan berbicara kritik secara personal kepada Moh. Sanoesi, padahal Soeroso sendiri bukanlah pengurus PKI. Akhirnya Soeroso mengaku salah, lalu dicabut lagi cerita mengenai kritik personal kepada Moh Sanoesi. Soeroso menyebutkan bahwa dirinya tidak ada prasangka buruk 
kepada PKI, dan PKI Bandung bersih. Semua audiens di vergadering bersorak dan berteriak PKI bersih! Soeroso kemudian menjelaskan asas PSI panjang lebar.

Asas PSI pada dasarnya menganut ajaran agama Islam berbeda dengan asas SI Merah yang kommunis. Soeroso tetap berbicara bahwa asas PSI yang berlandasan Islam sangat berbeda dengan PKI berlandasan komunis yang keluar dari agama. Kemudian keduanya saling bicara, hingga akhirnya ditenangkan oleh voorzitteren. Tibalah bagian PKI yang berbicara, berbeda dengan Soeroso dari PSI. Ketika pihak PKI berbicara di vergadering, para peserta vergadering sangatlah gembira, sorak sorai sampai tidak terdengar jelas karena sangat ramainya suasana pertemuan debat tersebut. Setelah dari pihak PKI selesai berbicara di vergadering debat dimulai.

Pihak PSI menceritakan dengan menjelek-jelekkan komunisme. Disebutkan bahwa komunis itu tidak bertuhan. "eta djalma communist mah heunteu bertuhan da PKI neutral tina agama ari PSI mah asasna ge dasar Agama Islam enz....” ("itu orang komunis tidak bertuhan karena PKI keluar dari agama, kalau PSI asasnya memakai dasar Agama Islam") vergadering lalu ribut minta untuk distop perkataan dari Soeroso, audiens berteriakteriak dari luar "parantos bae koelan" (sudahi saja tuan) dan "mangga bae tjalik" (silahkan saja duduk). Suasana riuh dan ribut ketika vergadering sering diperingatkan oleh voorzitteren. Dari pihak PSI banyak menanggung malu akibat sering diteriakinya ketika pihak PSI sedang berbicara dan berpendapat. Sampai speaker dari pihak PSI digunakan dan membacakan surat kabar Neratja yang menyebutkan bahwa komunis itu merusak agama, buktinya di Rusia masjid dipake rumah bola. Kemudian dari pihak PSI berbicara dari buku karangan Malaka menyebutkan... (belum lagi jelaskan) suara para audiens vergadering sudah sangat ribut berteriak "ngabobohong" dan "eta mah ngalamoen”.

Voorzittereun berdiri dan menenangkan suasana vergadering. Semua orang akhirnya tenang. Serangan PSI kepada PKI atau komunis dapat dibalas oleh PKI, vergadering kembali ramai dan riuh gembira. PKI menyebutkan bahwa surat kabar Neratja adalah surat kabar penyokong gerakan kapitalis ${ }^{11}$ akhirnya Kiai PSI tidak bisa bercerita lagi. Obrolan dari PSI dibalas dengan teriakan-teriakan audiens yang membela PKI. Melihat vergadering yang dilaksanakan di Bandung tersebut menghasilkan coreng muka karena dipermalukannya PSI.

\section{Perlawanan Gerakan Komunisme Melalui Surat Kabar Soerapati}

Perlawanan yang dilakukan oleh surat kabar Soerapati ini salah satunya tentang pajak yang mulai dijalankan pada tanggal 1 Januari 1924. Pajak ini adalah pengganti pajak landrente. Pengaturan pajak ini bukan menurut luas atau kelas tanah, melainkan besarnya sewaan rumah yang didirikan. Menurut Soem, penulis artikel ini jika dibandingkan dengan pajak landrente, pajak baru ini lebih memberatkan. Naiknya pajak tersebut bukan lagi ratusan persen melainkan ribuan persen. Soerapati selanjutnya melakukan kritik terhadap pemerintahan di Hindia.

Seseorang yang menggunakan insial nama A. menuliskan : "rakyat sengsara, negara binasa, rakyat makmur, negara tentram. Tidak akan ada negara jika tidak ada rakyat. Sangat salah ketika tidak ada negara tapi menganggap rakyat seperti bangkai, hidup rakyat pada saat ini. Zaman "kemodalan" adalah satu alat untuk mendatangkan hasil. Mengumpulkan keuntungan untuk satu dua orang yang berkuasa yaitu "kaum kemodalan", rakyat yang jumlahnya jutaan, hak menjadi manusia seakan sudah tidak ada. Diganti

\footnotetext{
${ }^{11}$ Sebenarnya surat kabar Neratja adalah surat kabar penyokong gerakan teosophie.
} 
dengan sifat "kamesinan" (dipaksa terus bekerja seperti mesin). Bagaimana nasib rakyat Hindia ? Rakyat sama sekali tidak pernah merasakan kenikmatan...rakyat dagingnya dari mana-mana dicubit, darahnya dihisap, kepalanya ditindih. Kuat - kuasa - merdeka, itulah. Kekuatan ada di rakyat, kekuasaan ada di rakyat, kemerdekaan ada di rakyat. Jika rakyat sehati di dalam gerakan bersama-sama. Karena sehati di dalam gerakan akan menjadi kuat. Karena kuat akan berkuasa. Akhirnya bisa merebut kekuasaan (Soerapati, 5 Februari 1924)".

Perlawanan seperti ini diperuntukkan bagi para penguasa. "Kamodalan" dapat diartikan sebagai pemerintahan kolonial atau pemerintahan daerah (lokal) yang sewenang-wenang terhadap rakyatnya. Perlawanan yang dilakukan oleh rakyat di Hindia akhirnya dilakukan. Perlawanan-perlawanan tersebut dilakukan dengan cara rapat-rapat akbar, vergadering. Dimaksudkan untuk menyatakan opini, keberatan terhadap kebijakan pemerintah (selanjutnya mengirim mosi). Perlawanan di surat kabar Soerapati oleh intelektual-intelektual komunis selanjutnya dengan kegiatan jurnalistik, dengan tulisan yang tajam dalam mengkritik pemerintahan.

\section{Peranan Surat Kabar Soerapati dalam Perlawanan kepada Pemerintahan Kolonial}

Bioskop Oriental Bandung pada tanggal 5 Oktober 1924 sangat ramai. Vergadering dilaksanakan di gedung bioskop tersebut. Vergadering tersebut dihadiri kurang lebih oleh 5.000 orang dan membahas mengenai Inlandsche Verponding dan Landrente. Seluruh peserta yang hadir dalam pertemuan akbar ini mengutarakan keberatannya, sehingga simpulan dari pertemuan tersebut menghasilkan mosi yang berisi agar pihak pemerintah kolonial mau menghapuskan pajak atau mengurangi pajak. Pada bulan Januari 1925 Soerapati pun menuliskan perkara Rakyat Leuwigoong yang melakukan protes terhadap Asisten Resident di Garut. Hal ini disebabkan rakyat di Leuwigoong tidak setuju dengan pemberlakuan pajak. Rakyat Leuwigoong protes membawa tanda tangan dan cap jempol kurang lebih 160 tanda tangan meminta supaya tuntutan rakyat Leuwigoong diperhatikan dan cepat diurus. Pada tanggal 17 Mei 1925 diadakan pertemuan akbar yang dihadiri oleh beberapa organisasi pergerakan seperti Budi Utomo, PKI, dan SI, Sarekat Ambon, dan Muhammadiyah yang membahas mengenai kritik terhadap pemerintah kota (Gemeenteraad). Pertemuan akbar ini diprakarsai oleh Budi Utomo. Hasil dari pertemuan tersebut dibuatlah mosi untuk dimuat di setiap surat-surat kabar.

1) Menghalang-halangi gemeenteraad Betawi, apalagi ketika sedang pemilihan.

2) Menuntut adanya alegemeene kiesrecht di dalam gemeente Betawi, supaya rakyat pribumi mempunyai wakil yang banyak.

3) Jika dua perkara di atas tidak berhasil, menuntut akan mengadakan Inlandsche gemeenteraad sendiri.

4) Jika tuntutan kedua dan ketiga tidak diperbolehkan, baiknya gemeente Betawi dibubarkan, dan diikutkan ke dalam Regentschapraad.

Selain kritik mengenai pajak, surat kabar Soerapati mengkritik pula kebijakan pengadaan alat perang. Seperti permasalahan sebelum tahun 1920 ketika SI cabang Semarang menolak keputusan Indie Weebaar, pada tahun 1924 dan awal 1925 kebijakan pengadaan perang yang disebut dengan Vloowet dikritik oleh surat kabar Soerapati. Perencanaan kebijakan vlootwet (pengadaan kapal-kapal dan perlengkapan untuk keperluan perang) oleh Colijn. Partai yang mendukung kebijakan tersebut adalah partai agama (Katolik dan Protestant), karena partai agama yang menyetujui usul tersebut surat kabar Soerapati memandang bahwa pada dasarnya agama itu harus tidak 
menyepakati perencanaan tersebut. Perang yang bertujuan saling membunuh tidak dibenarkan di dalam agama. Namun sayangnya karena agama sudah menggunakan kaca mata kapitalisme, perencanaan tersebut disetujui. Akan tetapi kebetulan salah satu dari anggota (yang berpaham humanis) di tweede kamer menolak usul tersebut. Akhirnya rencana vlootwet pun ditolak.

\section{Perlawanan Gerakan Komunis melalui Surat Kabar Soerapati kepada Pemerintahan Daerah}

Satu lurah (kepala desa) di salah satu desa, bawahan distrik Garut Selatan mempunyai sifat yang sangat tidak terpuji. Sikap dan sifat yang diperlihatkan dari keseharian pemimpin desa tersebut tidak mencerminkan sifat yang harus ditiru oleh masyarakatnya. Satu permasalahan, lurah tersebut mempunyai "boedjang awewe" bernama Toe'ah. Toe'ah sudah dilamar oleh Entoek. Satu pasal ketika Toe'ah tibatiba pulang pamitan kepada lurah untuk dipindahkan ke rumah saudaranya, lurah tersebut sangat marah. Dipanggilnya Entoek, dimarahi, diludahi dan dipukuli. Kedua, lurah tersebut mempunyai "landjang" anak saudaranya. Tinggal serumah dengan lurah tersebut. Penulis ini menyebutkan, bahwa ketika lurah tersebut mengambil kesempatan untuk berpaling dari istrinya. Lurah tersebut melakukan prilaku yang sangat tidak terpuji.

Soerapati menyebutkan bahwa lurah tersebut harus dilaporkan kepada Wedana untuk ditindak. Satu lagi perkara yang sangat serius, ketika pembuatan jembatan yang melibatkan banyak tenaga rakyatnya. Lurah tersebut memaksa agar pembuatan jalan tersebut diselesaikan secepat mungkin. Akan tetapi tidak seorang pun yang diberi uang atau upah, hasil dari pembuatan jembatan tersebut, padahal uang untuk pembuatan jembatan termasuk pembayaran upah untuk para kuli pembuat jembatan tersebut telah diberikan. Redakteur Soerapati menuliskan bahwa sikap dan sifat lurah tersebut sudah di luar kendali. Rakyat di desa tersebut harus segera melaporkan lurah tersebut kepada yang berwajib (Wedana).

Toegenah salah satu anggota SR mengkritik Lembaga Agama Bandung. Perkara ini adalah perkara buka waris $\mathrm{Nji}$ Oeskinah dari Bodolan Kecamatan Rancaekek. Buka waris tersebut menggantung di lembaga agama selama satu tahun. Uang untuk buka waris tersebut f 1800, diterima oleh Raad Agama f 900, f 900 lagi hasil dari penjualan sawah. Soerapati membuat pertanyaan: "Mahoer doeit oezoer teh? Leungit doeit oezoer teh?". Hal ini kenapa patut dipertanyakan, karena uang tersebut harus dibagikan kepada semua rakyat di Rancaekek dan Cicalengka. Supaya Raad Agama Bandung tidak ternoda, maka segeralah Raad Bandung memberikan jawaban untuk perkara ini. Selain dari perkara uang buka waris yang menjerat Raad Agama. “Toewang Artos?" atau (memakan uang) adalah perumpanan praktik korupsi yang dilakukan oleh Sahali seorang camat di Roempin bawahan distrik Bogor. Sahali mencuri uang untuk menyembelih sapi kepunyaan landheer Roempin. Sahali, Camat Roempin akhirnya mendapatkan hukuman satu bulan penjara.

Dalem Bupati Bandung Wiranatakusumah dikritik dengan sangat tajam dan pedas. Tidak sedikit di dalam surat kabar ini menulis keburukan bupati Bandung dari segi kehidupan pribadinya. Seperti contoh kecil, surat kabar Soerapati pada tanggal 22 Agustus 1925, memuat tulisan berjudul "Wiranatakoesoemah tingkeb". Moeharam atau Wiranatakoesoemah akan mengadakan selametan tingkeb, yaitu selametan 7 bulanan Nyai Oekon, istrinya. Dituliskan di akhir oleh redacteur Soerapati, "Moal engke ari geus ngadjoeroe diserahkeun deui mah?.

\section{Akhir Perjuangan Komunis melalui Surat Kabar Soerapati}

Polisi-polisi akhirnya dimasukkan ke setiap vergadering-vergadering. Hal ini 
bersifat rahasia. Oleh karena itu penangkapan-penangkapan bahkan penembakan terjadi kepada para anggota PKI bahkan redakteur surat kabar Soerapati. Kartawirja sebagai seorang verantw redacteur surat kabar Soerapati ini sangat sering keluar masuk penjara karena perkara yang berbeda-beda.

Penangkapan anggota PKI dan beberapa redakteur Soerapati yang terbit dari mulai tahun 1924 sampai 1925 di antaranya adalah: Muso, Poerwadinata, Sardjono, dan Kartawirja. Penangkapan Muso karena permasalahan demonstrasi setelah vergadering, Muso dipanggil ke landgerecht. Akhirnya Landrechter menjatuhi hukuman 8 hari penjara bagi Muso. Selanjutnya penangkapan Poerwadinata. Poerwadinata adalah salah satu ketua SR di Ciwidey, karena perkaranya ia dijatuhi hukuman 7 bulan penjara. Tanggal 14 bulan Juni ditangkap pula Sardjono karena permasalahan vergadering di Ciamis yang berujung kepada keributan. Sardjono pun dimasukkan ke dalam penjara sambil menunggu pengadilan untuk putusan hukuman. Mengenai permasalahan spreek delicht di Openbare vergadering SR Ciamis Kartawirja selaku Verantw Redacteur surat kabar Soerapati ikut ditangkap dan dimasukkan ke penjara.

Akhirnya pada tanggal 27 Agustus 1924 Muso keluar dari penjara. Sardjono dan Kartawirja sampai tanggal 3 Oktober belum juga diperiksa oleh polisi. Sarekat Rakyat akhirnya mengirim telegram ke pokrol jenderal, yang ditandatangani oleh Sambik Voorzitter SR untuk meminta Sardjono dan Kartawirja segera diperiksa. Kemungkinan Kartawirja telah keluar dari penjara pada tanggal 18 Desember, karena hal ini bersamaan dengan terbitan Soerapati tanggal 22 Desember 1924. Kartawirja sebagai verantw redacteur surat kabar ini sudah tidak memakai keterangan (di djero boewi). Kartawirja bahkan menulis perkara plv. Verantw redacteur nya Kartaatmadja yang dipanggil oleh pihak polisi karena tulisannya di Soerapati No. 29 (Surat kabar No. 29 ini di beslag).

Spreekdelicht di Openbare vergadering VSTP di Semarang yang dipimpin oleh Ali Archam berujung rusuh. Ali Archam pada waktu yang sama ditangkap dan dimasukkan ke penjara. Hasil putusan sidang pengadilan, Ali Archam dituntut 6 bulan penjara. Selain Ali Archam, seorang onderwijzer Rajatschool Tasikmalaya bernama Soepradja menerima besluit bahwa dirinya diskors karena keterlibatannya dengan SR. Soepradja tidak bisa mengajar selama satu tahun. Soepraja akhirnya dipanggil Hoofdbureau van Poitie Bandung pada tanggal 17 Februari 1925. Terkait penangkapan anggota PKI. Jahja, Oenoeng, Moelio yang sekarang dipenjara. Semua pertanyaan yang diajukan oleh polisi Soepraja menjawab "tidak tahu". Soerapati terbitan 14 Maret 1925 No. 9 menulis struktur redaktur baru. Awalnya ditulis redactrie bernama Siti Rajati, sekarang diganti dengan Kartaatmadja. Plv verantw redacteur menjadi $\mathrm{K}$. Karnawidjaja. Verantw redacteur sendiri pada pada tanggal 14 Maret 1925 berada di penjara lagi.

Kartawirja masuk penjara untuk kedua kalinya karena menghina pemerintah dan polisi. Dituliskan di dalam keterangan Soerapati Kartawirja dipenjara kedua kalinya di Bandung. Tidak hanya itu terbitan surat kabar Soerapati no.7 akhirnya dibeslag. Pada 8 April 1925 K. Karnawidjaja dipanggil oleh Hoofdbureau politie, untuk dimintai keterangan karena artikel yang ditulisnya "Ma'loemat $t i$ Hoofdbestuur PKI”. Artikel ini sebetulnya disalin dari surat kabar Api tanggal 24 Februari 1925 No.43. K. Karnawidjaja ditahan karena menyebarkan benih kebencian kepada pemerintah dan menghina polisi. K. Karnawidjaja adalah Plv. Verantw redacteur surat kabar Soerapati. Di samping itu surat kabar Soerapati yang seharusnya keluar pada tanggal 4 April 1925 No. 12 dibeslag untuk kedua kalinya oleh polisi. 
Beberapa orang yang dibuang karena gerakan revolusioner yang dilakukan di antaranya adalah Mardjohan, Darsono dan Ali Archam, Sneevliet, Brandsteder, Baars, Bergsma, Tan Malaka, Semaoen, H, Misbach, Datoek Batoeah, Natar Zainoedin, beberapa anggota PKI yang dibuang dengan cara halus di antaranya adalah Van Burink, Dekker, Njonja Sneevliet, Van Kondernoordit dan Van Munster. Di samping itu surat kabar Soerapati yang terakhir terbit pada tanggal 26 Desember 1925. Setelah itu surat kabar Soerapati sudah tidak ada lagi.

\section{PEN UTUP}

Perpecahan di tubuh SI pada dasarnya menjadi awal dari kemunculan organisasi yang berideologi komunis. SI yang telah terwarnai oleh ideologi komunis mengatasnamakan dirinya SR setelah putusan kongres CSI (SI sayap radikal) menolak putusan cita-cita Pan-Islamisme dan dikeluarkan dengan keputusan disiplin partai. Setelah itu SI Merah berafiliasi dengan PKI dan melaksanakan kongres pertamanya di Bandung dan di Sukabumi pada tanggal 4 Maret 1923. Salah satu putusan dari kongres tersebut adalah SI (bekas SI "Putih") dan SR (SI "Merah") akan selalu bersaing untuk membela kepentingan rakyat.

Putusan kongres PKI dan SI "Merah" di Bandung dan Sukabumi pada tahun 1923 melahirkan surat kabar Soerapati. Surat kabar Soerapati pertama kali terbit pada tanggal 20 Oktober 1923. Berbeda dengan surat Matahari yang pertama kali terbit pada tahun 1922. Surat kabar Soerapati resmi menjadi surat kabar penyokong gerakan komunisme di Jawa Barat. Ditambah dengan bahasa Sunda dalam setiap penerbitannya. Surat kabar Soerapati ini menjadi menarik ketika melakukan propaganda.

Peranan surat kabar penyokong gerakan komunisme selain surat kabar Soerapati pada awalnya tidak ada yang berbahasa daerah. Hampir semua surat kabar yang berafiliasi dengan PKI menggunakan bahasa Melayu sebagai bahasa pengantar dalam setiap penerbitannya. Surat-surat kabar ideologis selain surat kabar Soerapati terbagi menjadi dua. Pertama surat kabar yang berafiliasi dengan PKI (Sinar Hindia, Matahari, Soerapati) yang kedua surat kabar yang tidak setuju dengan ideologi komunis (Neratja, Kaoem Kita, Sipatahoenan). Beberapa debat secara ideologis di dalam media surat kabar selalu dituliskan. Seperti contoh kritik terhadap pertentangan di tubuh SI. Perpecahan SI dan SR ditulis oleh surat kabar Kaoem Kita dengan judul "yang melemahkan pergerakan bumiputra”.

Perdebatan di dalam media surat kabar oleh surat kabar Soerapati selalu dituliskan. Selain itu perdebatan yang selalu dituliskan oleh surat kabar Soerapati ini adalah perdebatan dalam pertemuan antara SI dan SR, surat kabar Soerapati menuliskan beberapa pandangan tentang jalannya vergadering (pertemuan) yang membahas ideologi SI dan SR. Seperti contoh pertemuan yang dilaksanakan di Bandung dituliskan di surat kabar Soerapati tentang jalannya pertemuan tersebut dan perdebatan yang terjadi antara SI dan SR.

Perlawanan gerakan komunis di Jawa Barat dengan media surat kabar Soerapati ini sangat agresif dalam melakukan kritik terhadap pemerintah. Perlawanan surat kabar Soerapati pada akhir tahun 1924 semakin banyak dan beragam. Pada tahun 1924 surat kabar Soerapati lebih banyak mendidik rakyat dan mempropaganda rakyat dengan ideologi komunis. Pada tahun 1925 berada perlawanan gerakan komunisme dengan menggunakan media surat kabar Soerapati di dalam titik puncak. Surat kabar Soerapati selalu di-beslag (dibredel) dan semakin banyaknya berita penangkapan anggota PKI menjadikan surat kabar Soerapati semakin berani dan tidak takut dalam mempropagandakan untuk melawan pemerintah dengan kritik yang tajam. Tidak hanya penangkapan akibat 
perlawanan yang dilakukan oleh beberapa intelektual pribumi yang berada di surat kabar Soerapati. Surat kabar Soerapati akhirnya harus disita dan dilarang terbit pada tahun 1925.

\section{DAFTAR SUMBER}

\section{Disertasi dan Jurnal}

Hardjasaputra, Sobana. A. 2002.

"Perubahan Sosial di Bandung 18101906. Disertasi. Depok: PPS Universitas Indonesia.

Tittenbrun, Jacek. 2013.

"Ralph Dahrendorf's Conflict Theory of Social Differentiation and Elite Theory" dalam Innovative Issues and Approaches in Social Sciences. Vol 6. No.3. Hlm 117138.

Salam, Muhajir. 2013.

Revolusi di Puseur Dayeuh" dalam Jurnal Soekapoera Institut. Vol 1. No. 1. Hlm 7182.

\section{Buku}

Garrghan, Gilbert J. S.J. 1957.

A Guide to Historical Method Vol I \& Vol

II. Fordham University Press: New York.

Goodman, Douglas J. dan George Ritzer. 2008. Teori Sosiologi Modern. Jakarta: Kencana.

Gottschalk, L. (2008).

Mengerti Sejarah. Jakarta: Universitas Indonesia Press.

Habermas, Jurgen. 2010.

Ruang Publik. Tej. Yudi Santoso. Bantul: Kreasi Wacana.

Hardiman, Budi. 2010.

Ruang Publik, Melacak Partisipasi Demokrasi dari Polis sampai Cyberspace. Yogyakarta: Penerbit Kanisius.

Herlina. Nina. 2008.

Metode Sejarah. Bandung: Satya Historika. et al. 2013.

Sejarah Provinsi Jawa Barat Jilid 2. Bandung : Yayasan Masyarakat Sejarawan Indonesia (YMSI) Cabang Jawa Barat.

Indonesia, Arsip Nasional Republik. 1975. Sarekat Islam Lokal. Jakarta: ANRI.

Kartodirdjo, Sartono. 2014.
Pengantar Sejarah Indonesia Baru: Sejarah Pergerakan Nasional dari Kolonialisme sampai Nasionalisme. Yogyakarta: Ombak.

Lapian et al. 2012.

Indonesia dalam Arus Sejarah, Jilid V Masa Pergerakan Kebangsaan. Jakarta: PT Ichtiar Baru van Hoeve.

Lombard, Denys. 2008.

Nusa Jawa: Silang Budaya, Jilid 1 Batasbatas Pembaratan. Jakarta: Gramedia Pustaka Utama dengan Forum JakartaParis dan Ecole Francaise d'ExtremeOrient.

McVey, Ruth. T. 2009.

Kemunculan Komunisme Indonesia. Jakarta: Komunitas Bambu.

Niel, Robert van. 1976.

Munculnya Elit Modern Indonesia. Bandung: Pustaka Jaya.

Pringgodigdo, A.K. 1994. Sejarah Pergerakan Rakyat Indonesia. Jakarta: Dian Rakyat.

Ricklefs, M.C. 2008. Sejarah Indonesia Modern 1200-2008. Jakarta: Serambi.

Shiraishi, Takashi. 2005.

Zaman Bergerak, Radikalisme Rakyat di Jawa 1912-1926. Jakarta: Pustaka Utama Grafiti.

Soebagijo. 1977.

Sejarah Pers Indonesia. Jakarta. Dewan Pers.

\section{Surat Kabar}

Kaoem Kita, No.9. 27 Oktober 1924

Matahari. No.10.17 April 1923. No. 8. 29 Februari 1924.

Sinar Hindia, 2 Februari 1924.

8 Mei 1924.

7 November 1924.

Soerapati, No. 3. 5 Februari 1924.

No. 5. 5 Maret 1924.

No. 8. 20 April 1924.

No. 2. 9 Januari 1925.

No. 31. 22 Agustus 1925.

No. 41. 7 November 1925.

Sora-Merdika. No. 10. 3 Agustus 1920. 